\title{
PRODUCTION MANAGEMENT PROGRAM OF GEN FM RADIO NETWORK
}

\author{
Shabrina Ayu Rosandhy \\ Faculty of Communication - Mass Media Management \\ The London School of Public Relations Post Graduate Programme \\ Shabrina_ar@yahoo.com
}

\begin{abstract}
These days, the growth of media usage has encouraged the development of new media in quantity and the form itself. With these amount of media development, it leads to the inevitable competition. Radio is no exception. Today, the phenomenon of Radio Network development in Indonesia is very rife. If we see this networking practice between radio(s), then we will find a strong bond that will give many advantages for the main radio of the holdings. However, Gen FM which has their radio network in Surabaya, gives the freedom to their radio network to grow by their own. In fact, both of these radio are successfully topped the Nielsen Research. This research uses qualitative method and aim to find out how the production management program conducted by Gen FM to its radio network. The result of this study indicate that the production management program on Gen FM radio runs very well in accordance with the elements of broadcasting management including planning, organizing, actuating, and controlling. Thereby, two of these radio network can compete on the top list of Nielsen.
\end{abstract}

Keywords: Broadcasting Management, Management Production, Radio, Radio Production, Radio Networks

\section{Introduction}

Nowdays, people are demanded with the fast access of information, that makes mass media as a part of human daily life. The ease of accessing information also brings the media closer to human activities. The increasing use of this media seems to have contributed to the increase in the number and form of media currently available. Although competition in modern media industries is very tight, radio still got a chance to play their role. It believes that radio is a trusted source of information. Even important news such as Indonesian independence is spread out through the radio.

"Since its inception, radio has become a powerful mass communication. In fact, radio was once mentioned as the fifth estate - the fifth power after newspapers. However, along with the development of technology, the radio also experienced a number of changes. (Astuti, 2013, p. 11) The presence of changes in the modern era also contributed to fierce competition in the radio industry. This has an impact on the rampant phenomenon of radio network development as an effort to widen business and broadcast coverage as said by Dimmick (in Rochimah, 2015) that the expansion of business size and audience expansion is the main reason for the emergence of networked radio management.

In the book Menjadi Broadcaster Profesional, Masduki (2004, p.31) expressed his opinion regarding the phenomenon of network radio which is considered as an economic and political phenomenon of radio with the expansion of listener markets and expansion of coverage, bargaining on one-door advertisements, centralization of broadcast messages. While the definition of the radio network itself according to Masduki $(2004$, p.31) is two or more radios that are interconnected in various ways and interests.

In Indonesia, the network model has been widely applied by several media companies, one of which is Mahaka Radio Integra (MARI). Currently MARI is a group of companies that houses seven radio stations. Previously MARI only had three radio stations namely Jak FM, Gen FM Jakarta and Gen FM Surabaya. Until 2017, MARI expanded its network by combining the Ramako Radio Group 
which includes Mustang FM radio, KIS FM, and Lite FM (later renamed MOST Radio) to be part of MARI. In the same year MARI also launched a new radio station called HOT FM. Thus, MARI directly manages 6 radios in Jakarta and 1 radio in Surabaya.

From various radio stations owned by MARI, only Gen FM has networks in other regions. Uniquely, these two radios can compete and occupy top positions in Nielsen. Based on data obtained from Gen FM regarding Nielsen's ranking in June 2018, Gen FM Radio Jakarta was in fifth place after four previous sequences were occupied by dangdut radio and Gen FM Surabaya was at number 6 competing with other radios.
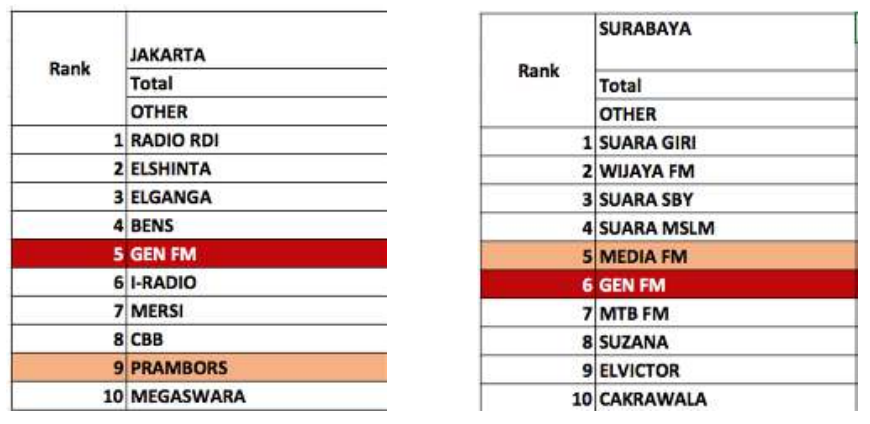

Figure 1: Increased of Gen FM Radio for Nielsen.

Seeing the phenomena that occur, it is interesting for researchers to know how Gen FM conducts program production management on its radio which currently operates not only in Jakarta but also in Surabaya. Researchers are interested in knowing whether there are similarities in the management of the two radios.

\section{Theorotical of Framework \\ Broadcast Media Management}

On Morissan book stated in regards to broadcasting management in his Manajemen Media Penyiaran (2008, p. 125) that the success of broadcast media depends on human creativity that works on the three main pillars which are vital functions of every broadcast media, namely engineering, programs and marketing. However, human quality alone is not enough if it is not accompanied by the ability of the broadcast media leader who manages existing human resources. Therefore, good management is considered absolutely necessary in the broadcast media.

The definition of broadcasting management itself in the view of Wahyudi (1994) is "management that is applied in broadcasting organizations, namely organizations that manage broadcasts, broadcast management as the driving force of broadcasting organizations in the effort to achieve common goals through broadcasting".

Pringle and Starr (2006) in Electronic Media Management explain the responsibilities of general managers in every operational aspect of a broadcasting station. In carrying out its management responsibilities, general managers carry out four basic functions:

Planning, includes the activities of determining the broadcast media objectives and preparing plans and strategies that will be used to achieve these objectives.

Organizing, is the process of formulating the organizational structure and responsibility of each resource in its position in accordance with the goals of the organization.

Directing and influencing, focused on efforts to stimulate the enthusiasm of employees to carry out their responsibilities effectively. Includes giving motivation, communication, giving direction and training.

Supervision, there are many designations for monitoring functions including evaluation, assessment and improvement. 


\section{Radio Program}

Pringle \& Starr (2006, p. 109) explain that the programming of most activities is dominated by one principal content element or sound known as format. From this explanation it can be concluded that some radio programs that exist today are dominated by content and sound elements. known as format.

The format in question is a framework, conceptualization of a broadcast station. Various radios have broadcast formats that are different from each other and are generally divided into the following groups:

a. Information Broadcast

b. Music-Information Broadcast

c. Music Broadcast. (Santana in Yusuf, 2016)

The format in question is a framework, conceptualization of a broadcast station. Various radios have broadcast formats that are different from each other and are generally divided into the following groups:

a. Information Broadcast

b. Music-Information Broadcast

c. Music Broadcast. (Santana in Yusuf, 2016)

However, another view was conveyed by Donnel (in Masduki, 2004) that the format of radio broadcasts is more than just music or entertainment, not only limited to programming but includes marketing as well as described in the following figure.

\section{Material and Methodology}

In the research on the production management of this radio network program, the methodology used is qualitative with the type of descriptive research and the method of collecting data through in-depth interviews. Qualitative descriptive was chosen because this research is suitable for using descriptive research because data collected in the form of words, pictures and not numbers. (Moleong, 2010, p. 11).

In addition, this research model is in accordance with the research that will be conducted, where the theory is used as the beginning of the question to answer the researchers' questions. "Theory is used as a tool, a measure and even an instrument to build hypotheses that later the theory will be used as a" horse's eye "in assessing the problems in his research" (Bungin, 2008, p.24 and p.26).

While the interview technique is chosen because researchers are considered to be more free in transferring information to the object of research and informants without being bound by the composition of questions that have been prepared in advance. (Patilima, 2007, p.65). For this reason, the researcher will interview three resource persons who have extensive knowledge related to the problems formulated in the study. The speakers who will be interviewed in this study are Dinda Yudhia Daud (Vice President of Mahaka Radio Integra Content), Nita Ristiani (Gen FM Jakarta Director Program), Putu Gede Francois (Director of Gen FM Surabaya), Bambang Herry (Music Coordinator Mahaka Radio Integra) and Ahmad Fathudin Zuhdi (Research and Development Mahaka Radio Integra).

\section{Analysis and Findings}

Gen FM is one of the radio stations owned by Mahaka Radio Integra which is for young people. Gen FM was formed on August 9, 2007, according to the radio frequency of 98.7 FM. Reviewed through the official website of Mahaka Radio Integra, it was written that this radio station won $22 \%$ share of all Jakarta radio listeners and was still number one in Jakarta. Gen also won several prestigious awards such as Favorite radio shows from Yahoo! OMG, The Phenomenal Radio Station from Rolling Stone Indonesia and also the Favorite Radio Brand from the Netizen Award Marketeers. In Gen FM's DNA Brand explained that the target audience is 15-29 years with status such as students, first jobber, office workers, housewives, entrepreneurs, drivers. Since the beginning of his presence, 
Gen FM has been consistent to continue playing the best Indonesian songs, this is in accordance with the tagline that he is carrying, the Indonesian Music Sound Generation. Currently, Gen FM radio is not only in Jakarta, but also in Surabaya with a frequency of 103.1 FM.

Based on interviews conducted by researchers, Gen FM as a broadcasting media carries out all broadcast management functions that include the functions of planning, organizing, directing and controlling. In carrying out the planning function, this organization is mature enough to prepare a strategy to achieve its objectives. Recognizing that the success of radio stations was measured through Nielsen research data, Gen FM management chose to form an R \& D division and rely on research data as a basis for determining the steps it took, uniquely not many other radio stations had Research and Development divisions to complement and support research results Nielsen.

Even for every broadcasting content selection broadcast both song and information, this organization really pays attention to every detail, everything is organized and always

based on research. One example is when they find out that the listener in Jakarta and Surabaya has a different character. So Gen FM Surabaya chose to adapt the radio program in Jakarta, but it was delivered in the local language, even though other radio stations that were competitor oriented to Jakarta. With this approach, listeners will feel closer and the message delivered is more easily accepted. This is also believed to be one reason for the success of Gen FM radio.

In connection with organizing, the form of networked radio practices that occurred on both radios turned out to be running in two directions. The Gen FM Surabaya network station was given freedom to explore but was limited to the approval given by the Vice President of Content. In its production activities, the Jakarta and Surabaya Gen FM radio programs were carried out by different teams but both were headed by the Vice President Content whose position was equivalent to that of the general manager, only in this organization was the Vice President Content. He is responsible for reporting to Chief Executive Officer (CEO) Mahaka Radio Integra.

Gen FM Surabaya Radio is still controlled from Jakarta but is given the freedom to explore as long as it is in line with the characteristics of the parent radio and get approval from the Vice President Content. In the direction function, the Vice President Content has an important role to carry out the briefing function. At Gen FM Surabaya, the Program Director held more control and became a bridge between the management team in Jakarta. For that, if there are problems in Surabaya that cannot be handled by the Program Director, then the Vice President Content will help deal directly.

However, the direction function is not only carried out by the Vice President of Content, the Program Director will also run the briefing function to the announcer, especially if the announcer is experiencing problems that cause the broadcast performance to decrease. In such cases, the Program Director will provide motivation so that broadcasters' broadcast performance can improve. Music Coordinator also gave directions to each Music Director to have the same perception. This is done so that Music Director can give the same assessment to the songs that will be broadcast and also to improve the quality of human resources in this organization.

With regard to the quality of human resources, this organization also provides training to each of its members. This training was provided by external parties who were consultants, namely Astro who was in Kuala Lumpur. Employees who are considered potentially will be sent to study directly there and are expected to be able to share their knowledge with other employees.

In addition, there is training between the Jakarta and Surabaya teams. Morning broadcasters and producers from Surabaya were sent to Jakarta to be able to see directly the production process in Jakarta. Then, the team from Jakarta also had the opportunity to come to Surabaya and provide training to the Gen FM Surabaya team. Even the entire division will carry out training provided by the MARI Institute division. Supervision and training is also an effort to maintain the balance of the path of the Gen FM radio broadcasting program to remain on the appropriate track. In addition, by sending employees to run training and transfer knowledge to others is also fairly effective and cost efficient.

Furthermore, there is a supervisory function in broadcast management. In the Gen FM radio production team, supervision was carried out based on the results of daily research from Consumer Relations Management (CRM), song research through x-rater, weekly data from the CRM and DGI Lab teams, annual Digital Music Test data, Nielsen research obtained three months once and also a survey conducted by the R \& D division. Through Nielsen's data, this radio can find out the number of listeners listening to the program. Then, CRM data and survey results will help this station to find out more deeply and analyze the problems faced. Audience response is also a consideration in evaluating 
the Gen FM radio broadcasting program. Audience response is important for this team, usually the response can be delivered through official social media accounts owned by Gen FM.

In addition, each broadcaster will choose the best cut broadcast to be used as evaluation material. But this is not going well in Surabaya, Program Director does not send the best cut announcer every day. However, every day the Program Director in Surabaya always listens and monitors the broadcasting directly, then reports once a week to the Vice President Content in Jakarta.

Another finding obtained by researchers is that until now, there were no programs from the main station that were broadcast relayed on network stations. All programs broadcast in Surabaya are produced by Surabaya's Gen FM team, although there are several programs that have similar treatments such as Wrong Connect, GANAS and Gen Choice Artists. In the Gen Choice Artist program, it is possible if there is a production of the Jakarta Gen FM team that is broadcast in Surabaya. Because this program is a program aimed at appreciating local musicians, it is necessary to have an interview with the musicians concerned. While the majority of Indonesian musicians live in Jakarta and this is an obstacle for Gen FM Surabaya, it is the result of interviews conducted by Gen FM Jakarta that will be broadcast on Gen FM Surabaya.

While most other networked radio broadcasts relay broadcasts and control of network stations is held entirely by the master station as an effort to expand the target audience and efficiency, this radio does not do the same thing. Gen FM chooses to adapt and repackage the program with an approach that is tailored to the character of the listener. However, this has succeeded in bringing Gen FM to be ranked top of Nielsen.

\section{References}

Astuti, S.I. (2013). Jurnalisme Radio Teori Dan Praktek. Bandung: Simbiosa Rekatama Media.

Bungin, B. (2007). Penelitian Kualitatif: Komunikasi, Ekonomi, Kebijakan Publik, dan Ilmu Sosial Lainnya. Jakarta: Kencana, 2008.

Mahaka Radio Integra. (N.d) is obtained from http://mari.co.id/radio/?l=1

Masduki. (2004). Menjadi Broadcaster Profesional. Yogyakarta: Pustaka Populer.

Moleong, L. J. (2010). Metodologi Penelitian Kualitatif. Bandung: Remaja Rosdakarya.

Morissan, M. A. (2008). Manajemen Media Penyiaran: Strategi Mengelola Radio \& Televisi. Jakarta: Kencana Prenada Media Group.

Patilima, H. (2007). Metode Penelitian Kualitatif. Bandung: Alfabeta.

Pringle, P.K., \& Starr, M.F. (2006). Electronic Media Management. USA: Focal Press.

Rochimah, I. (2015). Dinamika Kelompok-Kepemilikan Media Sebagai Proses Strukturasi Dalam Industri Media Di Indonesia: Studi Kasus Relasi Radio Induk Dan Radio Jaringan Dalam Kelompok Kepemilikan Radio Siaran Masima Radionet Dan Mahaka Media. Universitas Indonesia, Depok.

Wahyudi, J.B. 1994.Dasar-Dasar manajemen Penyiaran.Jakarta: Gramedia Pustaka.

Yusuf, F. (2016). Analisis Proses Produksi Program Berita Radio Metro Mulawarman Samarinda. eJournal IlmuKomunikasi, 4 (3), 98-111 